KaARle Wirta

https://orcid.org/0000-0001-7594-0804

Tampere University

Henri Hannula

https://orcid.org/0000-0002-3182-1800

University of Helsinki

Otso Kortekangas

https://orcid.org/0000-0002-6486-6239

KTH Royal Institute of Technology, Stockholm

\title{
DIPLOMACY OF AN EMPIRE. ALTERNATIVE AGENTS IN SEVENTEENTH-CENTURY SWEDEN
}

\section{STATE OF THE ART}

This issue is devoted to examining diplomacy in the Swedish Empire. For us, the empire is considered a methodological tool for examining seventeenth-century Sweden as an international connective arena for the circulation of people, goods and ideas. Inspired by recent developments in new diplomatic history, this issue investigates how various international connections have helped shape the Swedish Empire, focusing on people, places and resources. By combining recent scholarly research on early modern European empires with existing research on state formation, this issue aims to contribute to the current debates regarding European expansion in the early modern period. Studies by Lisa Hellman, Meike Von Bresicus, Allison Games, Gijs Dreijer and Elisabeth Heijmans, for example, illuminate this shift in perspective by 
exploring a multitude of actors, such as entrepreneurs and explorers, and by demonstrating the crucial roles they played in the building and maintaining of European empires. ${ }^{1}$

Recent historiography of early modern Europe has highlighted the significance of different interregional actors, with overlapping loyalties and interests, for state formation processes as well as for the building of early modern empires. This approach has widened the perspective of traditional forms of diplomatic history, as well as state formation, by challenging the older deterministic national narratives of sovereign states experiencing different teleological stages of state formation, developing from the early modern state to its modern equivalent. ${ }^{2}$

A wide range of scholarly studies, often identified as sharing the new diplomatic history approach, have analysed diplomatic relations through approaches from the cultural turn, including studies on the careers of diplomats, court etiquette as well as arts and culture. For early modern history, scholars have suggested broadening the interest in diplomacy towards including various and intermediary actors, such as consuls, merchants, manufacturers and scholars, all with special expertise and accumulated knowledge. ${ }^{3}$ Not all diplomatic means were reserved for

${ }^{1}$ Lisa Hellman, This House is not a Home: European Everyday Life in Canton and Macao 1730-1830 (Boston-Leiden: Brill, 2018); Meike Von Brescius, Private Enterprise and the China Trade: British Interlopers and Their Informal Networks (PhD dissertation, Warwick: University of Warwick, 2016); Elisabeth Heijmans, The Agency of Empire: Connections and Strategies in French Overseas Expansion (1686-1746) (Boston-Leiden: Brill 2019); Alison Games, The Web of Empire: English Cosmopolitans in an Age of Expansion, 1560-1660 (New York: Oxford University Press, 2008); Gijs Dreijer, 'The Afterlife of the Ostend Company, 1727-1745', The Mariner's Mirror, 105 , no. 3 (2019), 275-87.

2 Jeremy Black, History of Diplomacy (London: Reaktion Books, 2010), p. 64.

3 John Watkins, 'Toward a New Diplomatic History of Medieval and Early Modern Europe', Journal of Medieval and Early Modern Studies, 38, no. 1 (2008), 1-14; Louis Sicking, Maurits Ebben, 'Nieuwe diplomatieke geschiedenis van de premoderne tijd: Een inleiding', Tijdschrift voor Geschiedenis, 127, no. 4 (2014), 541-52; Maurits Ebben, 'Uwer Hoog Moogenden Onderdaenigsten Dienaers', Tijdschrift voor Geschiedenis, 127, no. 4 (2014), 649-72; Badeloch Noldus and Marika Keblusek (eds), Double Agents: Cultural and Political Brokerage in Early Modern Europe (Boston-Leiden: Brill, 2011); Tracey Sowerby, 'Early Modern Diplomatic History', History Compass, 14, no. 9 (2016), 441-56. 
the officials who were sent abroad by sovereigns. Instead, a wider range of people could combine the realm of diplomacy with other sectors of society. For example, discussing the relationship between empire and trade, Guido van Meersbergen shows that the Dutch East India Company officials were both envoys for the company and the Dutch Empire while simultaneously also operating as merchants. ${ }^{4}$

A recent analysis of subsidies by Svante Norrhem, Erik Thomson, et al. demonstrates that the roles played by intermediaries of different ethnic, religious and societal statuses were pivotal for coordinating the asymmetrical fiscal-military instruments between greater and lesser powers. By showing the pivotal roles of various overlapping formal and informal networks and agents in expanding early modern empires, both in Europe and overseas, this contribution emphasises a more complex nature of early modern European diplomatic activities than previously understood. ${ }^{5}$

The importance of individuals and their networks has also evolved into an important topic within Swedish state formation. Recent edited volumes by Knut Dørum, Mats Hallenberg and Kimmo Katajala, as well as Petri Karonen and Marko Hakanen, ${ }^{6}$ on the one hand, and by Leon Jespersen, ${ }^{7}$ on the other hand, demonstrate the importance of the interplay between the rulers, subjects and agents at various levels within the Nordic states. Additionally, studies by Heiko Droste, ${ }^{8}$ Leos

${ }^{4}$ Guido van Meersbergen, 'The Dutch Merchant-Diplomat in Comparative Perspective: Embassies to the Court Aurangzeb, 1660-1666', in Practices of Diplomacy in the Early Modern World c. 1410-1800, ed. by Tracey Sowerby and Jan Hennings (New York: Routledge, 2017), pp. 147-65. Similar type of agency in the context of Danish trade in Asia, Kaarle Wirta, Early Modern Overseas Trade and Entrepreneurship: Nordic Trading Companies (New York: Routledge, 2020).

5 Svante Norrhem and Erik Thomson (eds), Subsidies, diplomacy, and state formation in Europe, 1494-1789: Economies of allegiance (Lund: Lund University Press, 2020).

${ }^{6}$ Knut Dørum, Mats Hallenberg, and Kimmo Katajala (eds), Bringing the People Back In: State Building from Below in the Nordic Countries ca. 1500-1800 (New York: Routledge, 2021); Marko Hakanen and Petri Karonen (eds), Personal Agency and Swedish Age of Greatness 1560-1720 (Finnish Literature Society, 2017).

${ }^{7}$ Leon Jespersen, A Revolution from Above? The Power State of 16th and 17th-Century Scandinavia (Odense: University Press of Southern Denmark, 2000).

${ }^{8}$ Heiko Droste, Im Dienst der Krone: Schwedischen Diplomaten im 17. Jahrhundert (Berlin: LIT, 2006). 
Müller, ${ }^{9}$ Ann-Charlotte Scherer, ${ }^{10}$ and Erik Thomson ${ }^{11}$ contribute to understanding the variety of ranks and means in Swedish diplomatic history. These contributions show that the complex interplay between these actors formed the early modern state - both 'top-down' and 'bottom-up'.

Our current issue focuses on different forms of diplomatic activities in shaping the Swedish Empire. The thematic array includes topics related to the development of international trading organisations, questions of the rights and duties of international trade, the development of military apparatuses and agriculture through foreign expertise, and the maintenance of international relations both within and outside the conventional borders of cross-regional Europe. Therefore, this issue offers a broad perspective to study a cluster of international spheres in which diplomacy was deployed between empires. The various levels of agency examined here often interacted with the state, and they did not, however, necessarily represent the state. On the contrary, these actors could challenge the states in many ways. ${ }^{12}$ According to the Westphalian order, this calls into question the teleological focus on the state, which overlooks the importance of several layers of agency in shaping the empire. In the context of international arenas, these interactions between the individuals and the states force us also to reconsider the shaping of the Swedish Empire. ${ }^{13}$

The contributions in this issue argue that bargaining and negotiating at the international level increased in the context of the rising power of the Swedish Empire and general European expansion.

${ }^{9}$ Leos Müller, Consuls, Corsairs and Commerce: The Swedish Consular Service and Long-distance Shipping, 1720-1815 (Uppsala: Studia Historica Upsaliensia 213, 2004).

${ }_{10}$ Ann Charlotte Scherer, The role of diplomacy in Swedish foreign policy under Gustav II Adolph (Marburg: Tectum Verlag, 2016).

${ }^{11}$ Erik Thomson, 'For a Comparative History of Early Modern Diplomacy: Commerce and French and Swedish Emissarial Cultures during the Early 17th Century', Scandinavian Journal of History, 31, no. 2 (2006), 151-72.

12 Cátia Antunes, 'Free Agents and Formal Institutions in the Portuguese Empire: Towards a Framework of Analysis', Portuguese Studies, 28, no. 2 (2012), 173-85.

13 Henri Hannula, Free Ships, Free Goods. Dutch-Scandinavian Disputes upon Trade and Commerce 1675-1697 (Helsinki: University of Helsinki, forthcoming). 
The question is why the Swedish Empire needed a wide range of diplomatic means to interact in an international context. There is a lacuna in existing research regarding the broad impact that diplomacy could bring to the Swedish Empire. The contributions in this issue aim to demonstrate that the Swedish state was dependent on the developments of the empire. Although the Swedish state and Swedish Empire were not equivalent, the former depended on the development, expansion and preservation of the latter.

Following the agency of the individuals involved in the formation of the empire through diplomatic means serves as a favourable approach to answering the following research questions: (1) What was the role of the empire in the formation of the Swedish state? (2) How was the empire built by international networks of individuals? (3) Which new insights about early modern empires can be obtained through the approach borrowed from the field of new diplomatic history?

\section{SWEDEN AS AN EMPIRE}

In international historiography on early modern European expansion, the role of the Swedish Empire is often overlooked even though, as a Baltic empire, it constituted an integral part of this expansion. ${ }^{14}$ Throughout the seventeenth century, Sweden's rule extended outside of Sweden and Finland (the eastern part of the realm) into, for instance,

${ }^{14}$ Colonialism, in its early modern sense, is a term and theme that has gained a certain level of scholarly awareness in the Swedish context, see e.g. Historisk Tidskrift, no. 3 (2020), Gunlög Fur, Colonialism in the Margins, Linda Andersson Burnett, Itinerario, 33, no. 2 (2009); Daniel Lindmark. Although in some ways related to empire, the historiographical discussion about colonialism has different emphases, primarily being interested in the question whether and in what ways Scandinavian expansions compare to more conventional colonial expansions. The starting-off point for this body of research has often been deductive, exploring how Sweden fits into the Central European framework of a colonial power. Our aim is more inductive, primarily studying the various agents working for, in alliance with or in relation to Sweden rather than the structure of the empire. The research on Swedish colonialism is not treated more widely in this issue but we embrace the general idea of opening the study of Nordic expansions towards an international framework. 
Livonia in the south, Kexholm, and Ingria in the east, as well as into some northern German provinces (including Bremen, Pomerania and Cassuben). Sweden also made serious attempts to establish itself as a colonial power in North America, Asia and West Africa. ${ }^{15}$

Since this issue is about the connections of the Swedish Empire with the surrounding world, it is of primary importance to address what we mean by the term empire. As defined by Jane Burbank and Fredrick Cooper, 'empires are large political units, expansionist or with a memory of power extended over space, polities that maintain distinction and hierarchy as they incorporate new people'. ${ }^{16}$ The challenge with the concept is that it is difficult to find a universal definition of what an empire is. Here, we follow the functional perspective of Kenneth Pomeranz, who has convincingly argued that empires are polities whose rulers exercise power directly or indirectly over other societies and smaller units. ${ }^{17}$ The term empire helps us view seventeenth-century Sweden as an international connective arena for the circulation of people, goods and ideas. The instruments which the rulers used could vary and do not have to have been similarly applied everywhere. ${ }^{18}$

Empires are usually perceived as large political systems in which one power rules over a vast geographic area. This is why the discussions usually take power and influence as their points of departure, fuelling the discussions with questions regarding a specific empire's relative or absolute size. ${ }^{19}$ When it comes to the historiography of empires,

15 Wirta, Early Modern Overseas; Nils Erik Villstrand, Sveriges historia 1600-1721 (Stockholm: Norstedts, 2011).

16 Jane Burbank and Fredrick Cooper, Empires in World History Power and the Politics of Difference (Oxford: Princeton University Press, 2010), p. 8.

17 Kenneth Pomeranz, 'Social History and World History: From Daily Life to Patterns of Change', Journal of World History, 18, no. 1 (2007), 69-98.

18 Similarly argued by Paul Kramer, 'Power and Connection Imperial Histories of the United States in the World History', American Historical Review, 116, no. 5 (2011), 1348-91 (p. 1349).

19 Regarding the early modern period, historians tend to focus on the most famous examples - e.g. in the classical overview of empires, David Armitage (ed.), Theories of Empire, 1450-1800 (Brookfield, Vt: Ashgate, 1991), neglects the Swedish Empire altogether. Also, Burbank and Cooper overlook the Swedish Empire. Most recently the focus on empires has been on the most famous examples: Krishan Kumar, Visions 
historians tend to focus on one geographically bordered entity of power, which gives an impression of a singular - an empire. However, empires should also be studied in plural because empires could never function without people, ideas and connections outside of their perceived borders. Indeed, many strategic and vital ideas, people, goods and symbols entered empires from the outside. ${ }^{20}$

The seventeenth-century administrative structure of Sweden resembled many other contemporary European powers that are conventionally defined as empires. The early modern Kingdom of Sweden was undergoing a process of centralisation, but the kingdom was by no means unified. Kings did not rule with the same premises everywhere. In general, Sweden and Finland constituted the kingdom (Lat. regnum). In contrast, the realm (Lat. imperium) also included various provinces in the Baltic region and Germany under Swedish rule. These areas had various kinds of administrative relations to the Crown. ${ }^{21}$ However, Nils Erik Villstrand, Kasper Kepsu and Torbjörn Eng have shown that some areas did not fit neatly within the regnum/imperium dichotomy and Ingria, for instance, showed certain similarities with both political definitions. ${ }^{22}$

Different parts were annexed at different times and on different terms. The privileges, laws and rules varied. The Swedish Crown displayed its ambition for power through royal symbols. For example, the provincial coat of arms included all different annexed areas in the realm. Also, in the official state letters, the rulers introduced themselves as the Crown and the protector of the different areas belonging to both the kingdom and the realm. The Swedish Crown signalled that it ruled

of Empire: How Five Imperial Regimes Shaped the World (Princeton-Oxford: Princeton University Press 2020).

20 The Swedish monarch, as a Reichsfürst, was also a representative in the German Empire because he had a seat in the Imperial Diet. Similarly applied in Allison Games, The Web of Empire: English Cosmopolitanism in An Age of Expansion, 1560-1660 (New York: Oxford University Press 2008); Cátia Antunes and Amelia Polónia (eds), Beyond Empires: Global, Self-Organizing, Cross-Imperial Networks, 1500-1800 (Boston-Leiden: Brill, 2016).

21 The matters are more complex; see Villstrand, Sveriges historia, pp. 53-54.

22 Villstrand, Sveriges historia; Kasper Kepsu, 'The Unruly Buffer Zone: The Swedish Province of Ingria in the Late 17th Century', Scandinavian Journal of History, 42, no. 4 (2017), 414-38. 
over several territories and peoples, with varying relations to the Crown, under one ruler. $^{23}$

The Swedish supremacy in the Baltic lasted roughly from the beginning of the Vasa dynasty until the death of King Charles XII and the loss of the Great Northern War. ${ }^{24}$ The Swedish Empire, founded on the efficient use of its scarce resources, was also characterised by constant war, rivalry with the Danish Empire, participation in the Thirty Years War, and expansion to the east and the north. The spark for the expansive Swedish approach in the Baltic region was the rivalry between Denmark and Sweden. Since the fourteenth and fifteenth centuries, the two kingdoms fought for dominance in the Baltic Sea, both in economic and military terms. During the Nordic union (the Kalmar Union), Denmark was the stronger power but, from the late sixteenth century onwards, Sweden seriously challenged Danish dominance. Numerous battles between the two contenders escalated into full-blown wars on several occasions (e.g. 1563-70, 1611-13, 1644-45, 1675-79, 1700, 1707). However, this rivalry did not only play out on the waves and shores of the Baltic Sea. At the beginning of the seventeenth century, both powers began to focus on expanding beyond the Baltic sphere.

The Swedish Empire grew as a result of several armed conflicts, both internal and external, in which Sweden had been embroiled since, at least, the last days of the Kalmar Union. In order to defend its borders, Sweden was in constant need of resources; it also needed to be prepared to fight on the continent and the Baltic Sea. Consequently, Swedish rulers needed to find ways in which to finance the military apparatus. Internationally, seventeenth-century Sweden was primarily known for its trade in naval stores, such as iron, copper, wood and tar - all crucial for maintaining and building early modern empires.

Swedish expansion was directly related to the aspiration of gaining the monopoly of violence, a common goal in early modern European

23 Torbjörn Eng has shown how complex the articulation of the empire was. Torbjörn Eng, Det Svenska väldet. Ett konglomerat av uttrycksformer och begrepp frän Vasa till Bernadotte (Uppsala: Studia Historica Upsaliensia, 2001).

${ }^{24}$ Villstrand, Sveriges historia. The most recent and concise overview of Sweden as an empire, in English, is Paul Lockhart, Sweden in the Seventeenth Century (Basingstoke and New York: Palgrave Macmillan, 2004). 
state formation - with only short periods of volatile peace, Sweden was in an almost constant state of war from the 1650s until 1721. This was also why the Swedish military apparatus played a crucial role in the making of the empire. In a relatively poor and sparsely populated kingdom, the central issue was how to exploit the scarce resources in the most efficient manner. In order to develop an empire, all social layers were drawn into the project in one way or another. One of the central features was strengthening the tax base $-\mathrm{a}$ theme discussed by several contributions to this issue. ${ }^{25}$

\section{BEYOND THE STATE PERSPECTIVE}

In historiography that considers the early modern expansion of Sweden, two main questions are essential: (1) Why and how did the Swedish state expand, and (2) was the state a top-down or a bottom-up power entity?

Concerning the first question, early modern political expansion, especially in Europe, has often been analysed through the capacity and strength of the state. ${ }^{26}$ In the case of Sweden, the focus has usually been placed on examining how a relatively poor and underdeveloped state had managed to expand and develop into a Baltic power. The typical answer lies in the centralisation of the state, which has been discussed through the relationship between the economy and the military apparatus. ${ }^{27}$

25 Hakanen and Karonen, Personal agency, p. 14; Jan Glete, Swedish Naval Administration, 1521-1721: Resource Flows, and Organisational Capabilities (Boston-Leiden: Brill, 2009), Villstrand, Sveriges historia.

26 Studies of state formation connect to the Weberian tradition of understanding the state apparatus as enforcing power within a given territory.

27 Jan Lindegren, Makstatens resurser. Danmark och Sverige under 1600-talet (Uppsala: Manuscript, 1992); Sven Nilsson, De stora krigens tid. Om Sverige som militärstat och bondesambälle (Uppsala: Studia Historica Upsaliensia, 1990); Artur Attman, The Russian and Polish Markets in International Trade, 1500-1650 (Gothenburg: Gothenburg Institute for Economic History, 1973); Mats Hallenberg, Statsmakt till Salu: Arrendesystemet och privatiseringen av skatteuppbörden i det svenska riket, 1618-1635 (Lund: Nordic Academic Press, 2008); Artur Attman, Swedish Aspirations and the Russian Market during the 17th Century (trans. by Eva and Allan Green) (Göteborg: Kungl. Vetenskaps och Vitterhets-Samhället, 1985); Michael Roberts, Sweden's Age of Greatness, 1632-1718 (New York: St. Martin’s Press, 1973); Jörgen Weibull, Sveriges historia (Stockholm: Förlags AB Wiken Svenska Institutet, 2003). 
These two forces, military and economic, interplayed closely: Sweden expanded politically because it needed to defend its borders in all directions. The constant threat of war and the need for defence resulted in a military state. ${ }^{28}$ Maintaining this state required significant fiscal revenues. To satisfy them, a political and economic centralisation of the fiscal-military state was needed. ${ }^{29}$

The answer to the second question lies in the fact that Sweden experienced a relatively harmonious inner structure among its ruling elite prior to the end of the century. Unlike in, for example, France and England in the 1640s and 1650s, the interests of the elite were relatively well-balanced, and no serious internal conflicts broke out in Sweden. Instead, the kingdom could continue to concentrate its resources and focus on fighting its battles elsewhere. At the time, Sweden was a monarchia mixta..$^{30}$ The Crown was hereditary, but the king or queen was by no means absolute. The power was divided between the Crown, the council of the realm and the estates. ${ }^{31}$ In his classic work, Charles Tilly argues that early modern agrarian and relatively poor states like Sweden were based on coercion because the military apparatus required significant funds. This is why an almost coercive central administration was developed. ${ }^{32}$ The Swedish state strengthened its military capacity and accelerated its administrative apparatus in tandem, forming an entity known as the power state. ${ }^{33}$ The power state had full sovereignty over its

${ }^{28}$ Jan Glete, War and the State in Early Modern Europe: Spain, the Dutch Republic and Sweden as Fiscal-Military States, 1500-1660 (London: Routledge, 2002).

${ }^{29}$ Lindegren, Makstatens resurser; Nilsson, De stora krigens tid; Dag Lindström, Skrå, stad och stat: Stockholm, Malmö och Bergen ca. 1350-1622 (Uppsala: Studia Historica Upsaliensia, 1991).

${ }^{30}$ Nils Runeby, Monarchia Mixta. Maktfordelningsdebatt i Sverige under den tidigare stormaktstiden (Uppsala: Studia Historica Upsaliensia, 1962).

31 Villstrand, Sveriges historia, p. 254. The situation changed, however, after substantial domestic political reforms by Charles XI resulted in a special Swedish form of absolutism supported by new bureaucratic elite and rebellious freeholders (often mistaken as peasants in the scholarship).

32 Charles Tilly, Coercion, Capital and European States, AD 990-1992 (Oxford: Blackwell, 1992). Tilly's approach does not necessarily fit in the Swedish context, see Hakanen and Karonen (eds), Personal Agency; Glete, War, State.

33 Several chapters in Jespersen (ed.), A Revolution are also extensively discussed in Villstrand, Sveriges historia. 
territory and defended itself against both internal and external threats by legitimising a monopoly on violence. Karonen et al. point out that this argument needs to be nuanced: the Swedish state was not merely a top-down machinery. Instead, at the local level, the state functioned more through mediation and negotiation with local powers. Some of the latest research results on early modern Swedish state-building confirm that the state formation process was also carried out from the bottom up. ${ }^{34}$

Historians such as Michael Roberts, Nils Erik Villstrand, Lars Ericson Wolke, and Paul Lockhart discuss the Swedish expansion from a relatively marginal power into a Baltic empire in an international context. According to the British historian Michael Roberts, the Swedish state developed into an empire essentially by coincidence, that is, through a series of reactions to external threats. ${ }^{35}$ Following the same vein, Nils Erik Villstrand argues that the Swedish Empire was primarily a defensive empire of fear. Both Roberts and Villstrand argue that Sweden experienced external threats, which served as catalysts for building and maintaining an empire. According to this interpretation, the empire was not planned, built or improvised - it simply emerged. ${ }^{36}$ The Swedish historian, Lars Ericson Wolke, considers that the Swedish Empire suffered from its own built-in imperial dynamic: the very fact that the empire was forced to expand and constantly look for new buffers to protect its core led to the threat of the empire growing until it was too big to be controlled. ${ }^{37}$ This phenomenon is, however, not unique to Sweden. Indeed, it could be argued that this was the pattern that most early modern empires followed - if not all empires throughout history. If we take Jonathan Israel's classification of the development of the Dutch maritime trade empire as an example, then this pattern includes a time of imperial birth, rise, zenith, over-expansion and, finally, fall and decline. ${ }^{38}$

34 Dørum, Hallenberg and Katajala (eds), Bringing the People Back.

35 Michael Roberts, The Swedish Imperial Experience 1560-1718 (Cambridge: Cambridge University Press, 1979), see, especially, the first chapter.

36 Villstrand, Sveriges historia, p. 147.

37 Wolke, in Villstrand, Sveriges historia, p. 148.

38 Jonathan Israel, Dutch Primacy in World Trade, 1585-1740 (Oxford-New York: Oxford University Press-Clarendon Press, 1989). 
Harald Gustafsson and Torbjörn Eng show that the nature of Swedish power was in no way exceptional in Europe. ${ }^{39}$ With its varying relations to different parts of the realm, the Swedish state was a conglomerate state. ${ }^{40}$ It was, therefore, strikingly similar to other European - especially Iberian - states in which a composite monarchy was the norm. ${ }^{41}$ The annexed northern German provinces and its ambitions outside Europe provided the kingdom with a multifaceted character that certainly followed a conglomerate and an imperial model. ${ }^{42}$

This issue carries on the legacy of these seminal works, aiming to shift the focus from studying an early modern European empire through a 'singular' and a 'national' framework towards examining the empire as it appears through its international connections. We are less concerned with why Sweden, as a state, grew to become an empire but rather with why and how specific individuals and their networks influenced the Swedish Empire. The issue primarily focuses on the role played by the international diplomatic connections that the empire upheld and by which it was maintained. Thus, this issue paints a more dynamic, heterogeneous and less national picture of the Swedish Empire than previous works have conveyed.

\section{TOWARDS A NEW ANALYTICAL FRAMEWORK}

Scholars have begun to re-examine the dynamics of power and social organisation in early modern European empires in recent years. A growing

39 Earliest discussions about the relationship and role of the Crown vis-á-vis its provinces, in Jerker Rosén, 'Statsledning och provinspolitik under Sveriges stormaktstid', Scandia, 17, no. 2 (1946), 224-70.

${ }^{40}$ Eng uses the concept of konglomeratvälde to underline the structural composition of Sweden rather than the more functional focus on state-formation. Eng, Det Svenska väldet.

41 Different regions in these states were subordinated under the given state on different terms. Usually, these states were a diverse mosaic of different territories with separate political and judicial systems.

${ }^{42}$ Harald Gustaffson, 'The Conglomerate State: A Perspective on State Formation in Early Modern Europe', Scandinavian Journal of History, 23, nos. 3-4 (1998), 189-213; Michael Roberts, The Swedish Imperial Experience 1560-1718 (Cambridge: Cambridge University Press, 1979); see also, John Elliot, 'A Europe of Composite Monarchies', Past and Present, 137, no. 1 (1992), 48-71. 
number of studies on early modern empires are shifting focus from national paradigms to the complex interplay of various social groups with different origins. Rather than being restricted by national frames, empires are better characterised as a hybrid, heterogeneous and cross-cultural. ${ }^{43}$ This recent shift in paradigm shows that the most fruitful way to study empires is not always through the centralised systems of their metropoles but, instead, through the groups and individuals involved in the practical processes of developing, maintaining and representing these empires. ${ }^{44}$ Studies by Lisa Hellman, Meike Von Bresicus, Allison Games, Gijs Dreijer and Elisabeth Heijmans highlight the agency of different actors, such as bankers, private entrepreneurs, freighters, colonial governors, officers, merchants and explorers. ${ }^{45}$ Their findings underscore both differences and similarities in the dynamics of how different European regions endeavoured to maintain their imperial ambitions. Recent research has pointed out how social units with multinational and multicultural origins were keen to cooperate and appropriate, and challenge the upper levels of the empires' hierarchies. These recent developments in European historiography on empires align exceptionally well with the goals of new diplomatic history, highlighting various levels of agency of both state and non-state agents.

Similarly, the Swedish Empire also needed individuals capable of utilising these crucial elements inherent to modes of diplomacy. These individuals' vital role in empire-building manifests itself in their particular position as experts in the seventeenth century Swedish Empire. Without knowledge and expertise, there would not have been an empire - and without transregional intermediary actors, who had

43 Antunes and Polónia (eds), Beyond Empires.

${ }^{44}$ Similarly, in Kerry Ward, Networks of Empire: Forced Migration in the Dutch East India Company (Cambridge: Cambridge University Press, 2009); Christine Daniels and Micael Kennedy (eds), Negotiated Empires, Centers and Peripheries in the Americas, 1500-1820 (New York: Routledge, 2002).

${ }^{45}$ Lisa Hellman, This House is not a Home: European Everyday Life in Canton and Macao 1730-1830 (Boston-Leiden: Brill, 2018); Meike Von Brescius, Private Enterprise and the China Trade: British Interlopers and Their Informal Networks (PhD dissertation, Warwick: University of Warwick, 2016); Elisabeth Heijmans, The Agency of Empire: Connections and Strategies in French Overseas Expansion (1686-1746) (Boston-Leiden: Brill, 2019); Games, The Web; Dreijer, 'The Afterlife'. 
both connections and capacity to bargain and negotiate, there would have been no knowledge and expertise. Thus, Swedish empire-building and state formation was not possible without the contributions of these diplomatic actors. Each article of this volume contributes to the understanding of the role of diplomacy in a different and novel manner. ${ }^{46}$

\section{EMPIRE INTERACTION - DIPLOMACY OF AN EMPIRE}

The issue addresses how an empire was constructed by focusing on how the Swedish Empire had learned about institutional development from its European counterparts. This is discussed in depth in the article by Sebastian Schiavone and Otso Kortekangas and the one by Katja Tikka, Jaakko Björklund and Kaarle Wirta. The text by Tikka, Björklund, and Wirta emphasises the importance of business diplomacy in creating Swedish international trade. Schiavone's and Kortekangas's article illuminates the expectations and requirements of foreign know-how regarding military personnel and agricultural development in the Swedish Empire.

The text by Charlotta Forss studies the ways the empire was negotiated in cross-regional environments. Forss' article focuses on diplomatic envoys sent to the Ottoman empire, presenting the embassy of Claes Rålamb as the main case. In their contribution, Henri Hannula and Kaarle Wirta address how commercial diplomacy was deployed when Sweden negotiated with other powers, especially with its allies (the Dutch Republic) and rivals (the Danish Kingdom). Imperial power and posture were transmitted via diplomatic envoys in Baltic affairs. The contribution by Edgar Pereira addresses the importance of transmitting the empire through connections and economic diplomacy, showing how Portugal's relationship with Sweden was utilised to gain international recognition.

${ }^{46}$ For importance of foreign legal institutions and legal expertise in Sweden, see Erik Thomson, 'Swedish Variations on Dutch Commercial Institutions, 1605-1655', Scandinavian Studies, 77, no. 3 (2005), 331-46. For the role of the consular service in Swedish maritime trade, see Leos Müller and Jari Ojala, 'Consular Services of the Nordic Countries during the Eighteenth and Nineteenth Centuries: Did They Really Work?', in Resources and Infrastructures in the Maritime Economy, 1500-2000, ed. by G. Boyce and R. Gorski (Liverpool: Liverpool University Press, 2002), pp. 23-42. 
In conclusion, we want to emphasise that European empires did not evolve in a vacuum, separately from one another, but through constant interaction with other powers. In this regard, empires can be seen as a prism through which it is possible to examine several overlapping international processes with which Swedish power was entangled. ${ }^{47}$ In this special issue, empires are treated as heterogeneous platforms, where dynamic and mobile individuals crossed borders and could, during their lifetimes, gravitate towards and shift between different empires through formal or informal links. While competing, empires were prone to mimic one another and coexist within the same imperial spaces in which individuals also operated and moved around. Sweden was no exception. ${ }^{48}$

Kaarle Wirta $(\mathrm{PhD})$ - a specialist in early modern business history, lecturer at the Tampere University. He received his doctoral degree at Leiden University in 2018. Recently he has done research on the early modern Finnish tar trade in an international business context funded by Kone Foundation (Finland); e-mail: kaarle.wirta@tuni.fi

Henri Hannula - PhD student at the University of Helsinki (Doctoral Programme in History and Cultural Heritage). In his $\mathrm{PhD}$ thesis project Hannula is analysing the late 17th-century Dutch-Scandinavian commercial relations; e-mail: henri.hannula@helsinki.fi

Otso Kortekangas - PhD in History, a researcher at KTH Royal Institute of Technology in Stockholm, Sweden; e-mail: otso@kth.se

47 Similarly, in the recent work on empires by Kumar, Visions of Empire, p. 3.

48 Antunes and Polonia (eds), Beyond Global; Wirta, Early Modern Overseas; Games, The Web of Empire. 